\title{
The Discourse Analysis of Psychological Factors Influencing Interest Contention in Business Dispute Settlement: A Perspective of Discourse Information Theory
}

\author{
Tingting Guo ${ }^{1,2}$ \\ ${ }^{1}$ School of Foreign Languages, Zhongyuan University of Technology, Zhengzhou, Henan, China \\ ${ }^{2}$ School of Liberal Arts, Zhengzhou University, Zhengzhou, Henan, China \\ Correspondence: Tingting Guo, Zhongyuan University of Technology, No. 41, Middle Zhongyuan Road, \\ Zhengzhou 450007, China. E-mail: 532955649@qq.com
}

\author{
Received: February 16, 2019 Accepted: March 11, 2019 Online Published: April 20, 2019 \\ doi:10.5539/ijel.v9n3p176 URL: https://doi.org/10.5539/ijel.v9n3p176
}

\begin{abstract}
Interest contention which constitutes the kernel of business dispute settlement is one of the major issues to explore in the studies of business dispute and it structures the whole process of business dispute settlement from beginning to end. Under the influence of various factors, litigants with differing interest orientations and interest demands could make good use of a number of information resources for the purpose of communicating, defending and fighting for the interests of their own. The psychological factors in the context influence the distribution of discourse information resources in the interest contention in business dispute settlement. In view of this, the present study focuses on the discourse analysis of psychological factors influencing the interest contention in business dispute settlement at the stage of litigation from the perspective of Discourse Information Theory (DIT) (Du, 2007, 2013, 2015). It can be found that participants can utilize the psychological factors such as the intentions, consensus changes, and information sharing categories to affect interest contention in business dispute settlement.
\end{abstract}

Keywords: business dispute settlement, Discourse Information Theory (DIT), interest contention, psychological factor, courtroom discourse

\section{Introduction}

In the process of business dispute settlement, interest contention constitutes the kernel of business dispute settlement. Many scholars (e.g. Fan, 2007; Vestergaard et al., 2011) have conducted relevant studies concerning the influencing factors of dispute or conflict settlement and found that social, psychological and cultural factors could affect the settlement of conflict or dispute. The influencing factors include social, psychological and cultural factors and they have different manifestations under different circumstances. However, the present study only focuses on how psychological factors influence interest contention in business dispute settlement from the perspective of discourse information theory (DIT). Fan (2007) in her "Social System of Dispute Settlement" proposes the factors influencing dispute settlement. Among the factors, some are related to the psychological factors. Many scholars argue that the psychological factors affect the speaker's discourse (e.g., van Dijk, 2008; Vestergaard et al., 2011). In van Dijk's (2008) study, both social and cognitive dimensions have been examined and emphasized and van Dijk (2008) argues that both social and psychological factors affect the speaker's discourse. And Vestergaard et al. (2011) propose a practice-oriented model of five dimensions of conflict, namely, structural, instrumental, interest, value or personal dimension. Moreover, Vestergaard et al. (2011) argue that the personal dimension is an important perspective to settle conflicts and this dimension is related to the psychological factors. Thus, the psychological factors have been regarded as a key perspective in influencing the dispute settlement. When people are in conflict, they usually have a need that has not been met. This need is often linked to one or more of the five different dimensions.

\section{Previous Studies on Discourse Information Theory (DIT)}

$\mathrm{Du}$ (2007) puts forward the linguistic model of information structure of legal discourse, and this is the core model of Discourse Information Theory. Based on this core model, the Discourse Information Theory has been developed systematically by researchers (e.g., Du, 2007, 2009, 2013, 2015; Zhao, 2011; Chen, 2011; Pan \& Du, 
2011; Huai, 2014; Huang, 2012; Ge, 2014; Xu, 2013; Zhang, 2016; Guan, 2015; Sun, 2016; Yue, 2016; Guo, 2017) for more than ten years.

In contrast to the common practice to consider information as a sentence-level notion, $\mathrm{Du}$ (2015) defines information as propositions which are the minimal communication units with a relatively independent and complete structure. $\mathrm{Du}$ (2007) puts forward the linguistic model of information structure of legal discourse, and this is the core model of Discourse Information Theory. A series of theoretical and applied studies of DIT are conducted based on this core model.

On the one hand, a number of studies have made further contributions to the theoretical development of DIT. Models and frameworks have been put forward to help solve different problems in the fields of linguistics, forensic linguistics and business English studies in particular (e.g., Zhao, 2011; Chen, 2011; Du, 2015; Xu, 2013; Ge, 2014; Zhang, 2016; Guan, 2015; Sun, 2016; Yue, 2016; Guo, 2017).

On the other hand, through years of research and development, the Discourse Information Theory (DIT) and Discourse Information Analysis (DIA) have been applied to legal discourse analysis (Du, 2015; Ge, 2014; Pan \& $\mathrm{Du}, 2011$; Xu, 2013; Zhang, 2016), legal translation and interpreting (Zhao, 2011), legal English teaching (Chen, 2017), authorship attribution (Zhang, 2016), forensic speaker recognition (Guan, 2015), conflict management in business meetings (Yue, 2016), interest contention in business dispute settlement (Guo, 2017; Guo, Zhao, \& Han, 2019) and automatic information processing (Du, 2015, p. 368; Sun, 2016).

\section{Theoretical Framework and Methodology}

\subsection{Discourse Information Theory (DIT)}

The tree information structure of legal discourse ( $\mathrm{Du}, 2007,2015)$ is regarded as the basic and core framework of Discourse Information Theory.

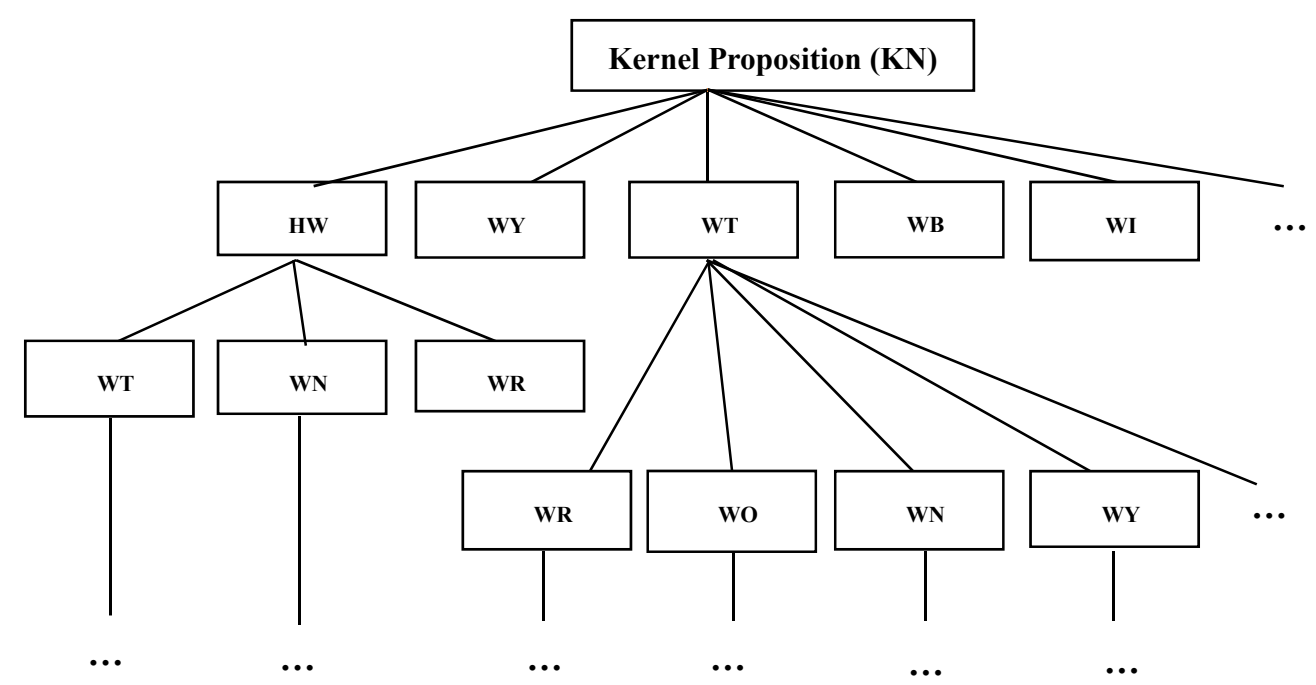

Figure 1. Tree information structure of discourse information theory ( $\mathrm{Du}, 2015)$

As is shown in Figure 1, a discourse is a hierarchical structure consisting of proposition-based information units that are the minimal, integral and meaningful units that have relatively independent complete meaning and structure. In the development of discourse, the proposition-based information units are woven into an information network and they are related to each other in one way or another. This view of discourse is regarded as the core model of Discourse Information Theory, namely the tree information structure of Discourse Information Theory ( $\mathrm{Du}, 2013,2015)$.

In a discourse, each information unit interrelates with other information units in such a way that a subordinate information unit develops its super-ordinate information unit in a certain way. This kind of relationship between subordinate information unit(s) and super-ordinate information unit(s) is termed as information knot (Du, 2013, 2015).

In DIT (see Du, 2015, pp. 30-31), information knots are represented by 15 interrogative words, namely, What 
Thing (WT), What Basis (WB), What Fact (WF), What Inference (WI), What Disposal (WP), Who (WO), When (WN), Where (WR), How (HW), Why (WY), What Effect (WE), What Condition (WC), What Attitude (WA), What Change (WG) and What Judgment (WJ).

\subsection{Research Methodology}

The present study mainly adopts the qualitative research method with the assistance of the corpus CLIPS. Specifically, the methods of discourse analysis, Discourse Information Analysis (DIA) and corpus study are employed as the major methodologies for data analysis in the present research.

\subsubsection{Data Collection}

In order to ensure the reliability and validity of the study, all the data are extracted from CLIPS (the Corpus for the Legal Information Processing System) which consists of transcripts of Chinese and American civil court trials. The data collected are mainly recordings of observed court proceedings, which were collected with professional digital voice recorders with the permission of the court and the consent of both parties (Ge, 2014). All of the discourses in CLIPS have been transcribed and tagged according to transcription and tagging conventions based on Discourse Information Theory (DIT).

\subsubsection{Data Analysis}

The data analysis can be illustrated by the following sample:

Sample:

01 [审判长]: $<1,2,2,14, \mathrm{WT}>$ 现在核对证据 提交情况。<2,14,3,26,WF1 $>$ 原告庭前向 本院提交了几份证据?

02[原告代理律师]: $<2,14,3,26, \mathrm{WF} 2>$ 原告 庭前向法院提交了 9 份证据。

03 [审判长]: $<2,14,3,27, \mathrm{WF} 3>$ 被告收到了 吗?

04 [被告代理律师]: <2,14,3,27,WF4>收 到。
$01[\mathrm{~J}]:<1,2,2,14, \mathrm{WT}>$ Now check the evidence submitted. $<2,14,3,26$,WF1 $>$ How many copies of evidence has the plaintiff submitted to the court before the hearing?

02[PA]: $<2,14,3,26, \mathrm{WF} 2>$ The plaintiff has submitted 9 copies of evidence to the court before the hearing.

$03[\mathrm{~J}]:<2,14,3,27, \mathrm{WF} 3>$ Has the defendant received them?

$04[\mathrm{DA}]:<2,14,3,27, \mathrm{WF} 4>$ The defendant has received them.

As is illustrated in the above sample, the numbers before the square brackets refer to the turns of speech. The symbols in the angle brackets are the description of the characteristics of information units. Numbers "1, 2, 2, 14" at the very beginning of the transcription represent the level of the information unit in the whole discourse, that is, the 14th unit of the 2nd level ("2, 14"), with its super-ordinate unit being the 2 nd unit of the 1st level ("1, 2").

And the signs of information level can help to locate specific information units in the whole discourse. "WT" and "WF" refer to the types of information knots, namely, "What Thing" and "What Fact" respectively. "J" refers to the chief judge, "PA" refers to the plaintiff's attorney and "DA" refers to the defendant's attorney.

\subsubsection{Research questions}

In order to achieve the research objective, two research questions are formulated as follows:

1) What psychological factors influence the interest contention in the courtroom discourse concerning business dispute settlement?

2) How does the specific psychological factor influence the interest contention in business dispute settlement from the perspective of Discourse Information Theory?

\section{Psychological Factors Influencing Interest Contention in Business Dispute Settlement}

In this section, we will discuss how the psychological factors influence the process of interest contention in business dispute settlement at the stage of litigation. And relevant psychological factors are demonstrated from the effects of intentions, consensus change, and information sharing category.

\subsection{Discourse Analysis of the Effect of Intentions}

van Dijk (2008, p. 81) defines intentions as (part of) mental models and intending an action is constructing a mental model of an ongoing or future fragment of conduct. For interaction in discourse and talk to be possible at all, participants need to represent the intentions of the other participants as well as their own. 
Besides, intentions are different from goals which are the same as purposes in van Dijk's definition, namely mental models of actions and their wanted consequences.

Intentions, the starting point of a discourse, relate to information potential energy closely. And this information potential energy is the prerequisite of communication according to Discourse Information Theory (Du, 2015).

According to DIT, the party who has owned more information possesses more information potential energy and the communication develops from the party with more information potential energy to the one with less.

If the party with more information potential energy does not want to promote the initiation and development of a discourse or communication, then the discourse or communication would not start or develop further. Thus, the information potential energy in the participants' intentions plays a key role in the manipulation of interest contention in business dispute settlement. For example,

\section{Extract 1}

01 [审判长]: $<\mathrm{WT} 1>$ 你可以选择说我把 手机号公开, 把电子邮箱公开, 是这样 吗?

02[证人]: $<\mathrm{WA} 1>$ 是啊。 $<\mathrm{WF} 1>$ 我选择 公开了别人就可以看到。

03[审判长]: <WT2 $>$ 只要是微博实名认 证的用户包括自己选择可公开的信息, 那么通过被告软件登录的时候就可以 看得到, 是吧? 是这个意思吗?

04[证人]: <WA2 $>$ 我不知道您这个逻辑 和微博。 $<\mathrm{WF} 2>$ 是这样的, 我进来之后 我会需要填写我的信息, 我的个人信 息, 我只不过使用 $x \times$ 微博登录, 省去我 登录这个过程, 但是我进了被告 $x \times$ 软件 之后, 我要再填写我的个人信息呀。

05[审判长]: $<\mathrm{WT} 3>$ 我再简单地说明一 下, 在 2014 年 $7 、 8$ 月份之前你是 $\times \times$ 微博的实名认证用户吗? 是不是?

06[证人]: $<\mathrm{WA} 3>$ 是。

07[审判长]: $<\mathrm{WT} 4>$ 那你简单地描述一 下在 2014 年 7、8 月份之前你作为 $x \times$ 微博的实名认证用户你通过 $x \times$ 微博登 录被告软件你可以看到你的互为好友 的 $x \times$ 微博的这些好友的哪些信息? 你 现在想得起来的那些是什么? 直接说 就可以。

08[证人]: $<\mathrm{WF} 3>$ 就是他的名字啊, 他 的比如说工作经历啊。

09[审判长]: <WT5 > 学校能看到吗?

10[证人]: <WF4 $>$ 学校他如果写了我就 能看到啊。

11[审判长]: $<\mathrm{WT} 6>$ 手机号和邮箱呢?

12[证人]: $<$ WT7 $>$ 手机号、邮箱如果, 你说互为好友的关系下吗?

13[审判长]: $<$ WA4 $>$ 对。

14[证人]: $<\mathrm{WF5}>$ 互为好友的关系下可 以看到啊, 但是在互为好友的关系下, 并且我有他的手机号我才可以看到。
01[J]: <WT1 $>$ You mean that I can choose to make my phone number, e-mail be public, is that right?

02[W]: <WA1 > Yes. $<$ WF1 $>$ If I chose to put them public, then other people can see them.

$03[\mathrm{~J}]:<\mathrm{WT} 2>$ As long as you are the user of micro-blog identified through real-name authentication, then you can see the information which is allowed to go public by other users of the blog when you login in the micro-blog through defendant's $\times \times$ software, can't you? Do you mean that?

04[W]: <WA2> I don't understand your logic and the micro-blog. $<$ WF $2>$ It is like this way, after I login in the blog I will need to fill out my information, my personal information. I just login in by $\times \times$ micro-blog to omit the process of login, but after I have entered the defendant's $x \times$ software, I have to fill out my personal information again.

05[J]: <WT3 $>$ I will make a brief explanation, are you the user identified through real-name authentication of $x x$ micro-blog before the July and August of 2014? Aren't you? $06[\mathrm{~W}]:<\mathrm{WA} 3>$ Yes.

07[J]: <WT4> As a user through the real-name authentication of the micro-blog, then you describe simply what information of your mutual micro-blog friends can you see when you login in $x \times$ software by means of your micro-blog before the July and August of 2014? Now what information can you remember? It's OK to speak them out.

08[W]: <WF3 $>$ It is his name, for example, his work experience.

09[J]: <WT5 $>$ Can the information about the user's schools be seen?

$10[\mathrm{~W}]:<\mathrm{WF} 4>$ If he wrote the information about his school then I could see it.

$11[\mathrm{~J}]:<\mathrm{WT} 6>$ What about the phone number and e-mail?

12[W]: $<$ WT7 $>$ Phone number, e-mail and do you mean that if we are mutual friends?

13[J]: $<$ WA4 $>$ Yes.

14[W]: <WF5 $>$ We can see those information if we are mutual friends, however, under the condition that we are mutual friends, I can see those information if I have his phone number at the same time. 
In Extract 1, in respect to information potential energy, the witness for the defense who has been the user of $\times x$ micro-blog and the user of the defendant's $x \times$ software at the same time for several years has worked in the marketing department of the defendant's $\times \times$ software; therefore, she must be quite familiar with relevant characteristics and information of the web-pages on both $\times \times$ micro-blog and $\times \times$ software.

Compared with the chief judge, the witness for the defense owns more information concerning the relevant characteristics of the two web apps; therefore, the witness for the defense is the party who has higher information potential energy. In other words, the witness for the defense can control the flow of information owing to this higher information potential energy to a certain extent. In spite of this, the flow of information is also affected by the chief judge's allocation of speech turns.

Based on the above analysis, it can be found that the witness for the defense owns higher information potential energy. However, WA2 starts to show that the witness for the defense is not so cooperative with the chief judge, which creates the difficulty in achieving effective information wanted by the chief judge. Thus, the chief judge has to adopt a series of WT information units (including WT2, WT3, WT4, WT5 and WT6) to reinitiate the questions to ask the witness for the defense in various ways in order to obtain the information wanted.

Even so, the witness for the defense has only assigned a portion of information in her grasp as the answers to the chief judge's questions and has avoided supplying more detailed information which is known by her, because the more detailed information may not be in favor of the defendant's interest contention. For example, in this extract, WA2 and WF2 divert to the details concerning the login process rather than whether relevant information can be seen which is asked by the chief judge. WF3 offers insufficient information to the chief judge. After that, WF4 uses an indirect way to answer whether the school information can be seen. WT7 is used by the witness for the defense to postpone answering the chief judge's questions. WF5 still provides insufficient and incomplete information the chief judge wanted and emphasizes the conditions when the information can be seen.

From the above data analysis, it can be seen that the intentions of the witness for the defense manipulates the information flow in the interactions between the chief judge and her. Since the information wanted by the chief judge is not in favor of the defendant's interest contention, the witness for the defense adopts the relatively uncooperative way to deal with.

Apart from the close relationship of intentions and information potential energy in interest contention in business dispute settlement, different intentions of each disputing parties can be found in the different amounts and different types of information units in interest contention.

\section{Extract 2}

01 [审判长]: $<1,2,2,15, \mathrm{WT} 14>$ 下面, 首先 针对关于原告被告主体是否适格的证 据进行举证、质证。<2,15,3,33,WT15> 首先由原告举证。

02[原代一]: $<3,33,4,19, \mathrm{WF} 1>$ 原告的那 个第一组证据, 证据 1 是 ...... 。 $<3,33,4,20, \mathrm{WF} 2>$ 那么, 证据 2 是...... $<4,20,5,18, \mathrm{WF} 3>$ 这个公证书显示的 呢, ...... $<4,20,5,19$, WF4 $>$ 第 4 页有相 关软件的产品列表和 logo、标记, $<4,20,5,20$, WF5 $>$ 那么第 15 页有关于原 告安全浏览器的使用协议, $<4,20,5,21$,WF6 $>$ 那么, 第 23 页显示的 是...... $<4,20,5,22, \mathrm{WF} 7>$ 那么, 第 27-28 页显示的是 .....。 $<4,20,5,23, \mathrm{WF} 8>$ 那 么, 33 页呢, ...... < <4,20,5,24,WF9> 那么, 通过第 34 页, 我们看到...... $<4,20,5,25$,WA1 $>$ 综合证据 2 来证明的 目的是：原告产品是原告经营的产品, 原告汶览器是原告经营的产品, 那么, 原告是原告相关一系列浏览器的权利 人。<3,33,4,21,WF10 $>$ er 证据 3 呢，... 那么进一步证明原告浏览器是原告经
$01[\mathrm{~J}]:<1,2,2,15$,WT14 $>$ Next, firstly, present and challenge evidence concerning whether the plaintiff and the defendant are the eligible subjects of the law case. $<2,15,3,33$,WT15 $>$ At first, the plaintiff presents the evidence.

02[PA1]: $<3,33,4,19, \mathrm{WF} 1>$ The plaintiff's first set of evidence, evidence 1 is that... $<3,33,4,20$,WF $2>$ Then, evidence 2 is that... $<4,20,5,18, \mathrm{WF} 3>$ The certificate shows that... $<4,20,5,19$, WF4 $>$ On page 4 , there are related software product list and logo, tags..... $<4,20,5,20$,WF5 $>$ Then on page 15 there is the usage agreement on the plaintiff's secure browser,.... $<4,20,5,21$,WF6 $>$ Then, page 23 shows that.... $<4,20,5,22$,WF7 $>$ Pages 27-28 show that.... $<4,20,5,23$,WF8 $>$ So, on page $33, \quad \ldots$. $<4,20,5,24$,WF9 $>$ Then, through page 34 , we see.... $<4,20,5,25$, WA $1>$ Comprehensively speaking, the purpose of evidence 2 is to prove that: the plaintiff's products are the products of the plaintiff, the plaintiff's browser is the products of the plaintiff, so the plaintiff is the right holder of a series of relevant browsers. $<3,33,4,21$,WF10 $>$ The evidence 3 is..., then it further proves that the plaintiff's browser is the plaintiff's products, this is the first set of 
营的产品，第一组证据。

03[审判长]: $<2,15,3,34, \mathrm{WT} 16>$ 被告发 表质证意见。

$04[$ 被代一]: $<3,34,4,22, \mathrm{WB}>$ 根据原告 所诉事实, 本案适用反不正当竞争法第 14 条的后半段, 就是 ...... $<3,34,4,23$, WA2 $>$ 本案原告是原告网站 的这个所有和经营者, 原告网站对一些 软件产品这个提供下载服务, 但这个不 等于他就是软件的所有者和经营者。 $<3,34,4,24, \mathrm{WF} 11>$ 原告在刚才这组证据 中提出有原告安全浏览器, 但是本案事 实很清楚, 同样按照原告的相关证据, 本案涉案的事实指向的是原告手机汶 览器, 不是安全汶览器。 $<3,34,4,25, \mathrm{WF} 12>$ 原告在这组证据中曾 经有一个 2002 年 1 月份这个上线的原 告手机汶览器, 但是版本是 1.6.1, 不 是本案涉案发生时间实际的使用者应 用的原告手机汶览器。 $<3,34,4,26$, WA3 $>$ 因此, 本案诉争指向 的是原告的商品的声誉是不是受到诋 毁, 而商品作为软件, 原告没有证据证 明他是所有者和经营者, 因此我们不认 为原告主体适格, 完毕。 evidence.

$03[\mathrm{~J}]:<2,15,3,34$,WT16 $>$ The defendant issue the comments on challenging evidence.

$04[\mathrm{DA} 1]:<3,34,4,22, \mathrm{WB}>$ According to the facts of the plaintiff's litigation, this case applies to the second half of article 14 of the Anti-Unfair Competition Law, that is.... $<3,34,4,23$,WA2 $>$ The plaintiff is the owner and operator of the plaintiff's website which provides download services for some software products, but it does not mean that the plaintiff is the owner and operator of the software. $<3,34,4,24$, WF11 $>$ The plaintiff has just put forward the plaintiff's safe browser in this group of evidence, but the fact is very clear, also according to the plaintiff's evidence, the facts involved in this case is the plaintiff mobile browser rather than a secure browser. $<3,34,4,25$,WF12 $>$ In this group of evidence, the plaintiff has proposed the plaintiff's mobile browser which is on the line in January 2002, but the version is 1.6 .1 which is not the plaintiff's mobile phone browser used by the actual users at the time when the case occurred. $<3,34,4,26$, WA $3>$ Thus, the dispute focus of this case is concerned with whether the plaintiff's product reputation has been discredited. But the commodities as the software, the plaintiff has no evidence to prove that he is the owner and the operator, so we do not think that the plaintiff is the eligible subject of this case. It's over.

As is shown, in Extract 2, utterances 01 and 02 are the plaintiff's evidence presentation regarding the issue of whether the plaintiff is the eligible subject of this case, while utterances 03 and 04 are the defendant's challenge on the plaintiff's evidence presentation on this issue.

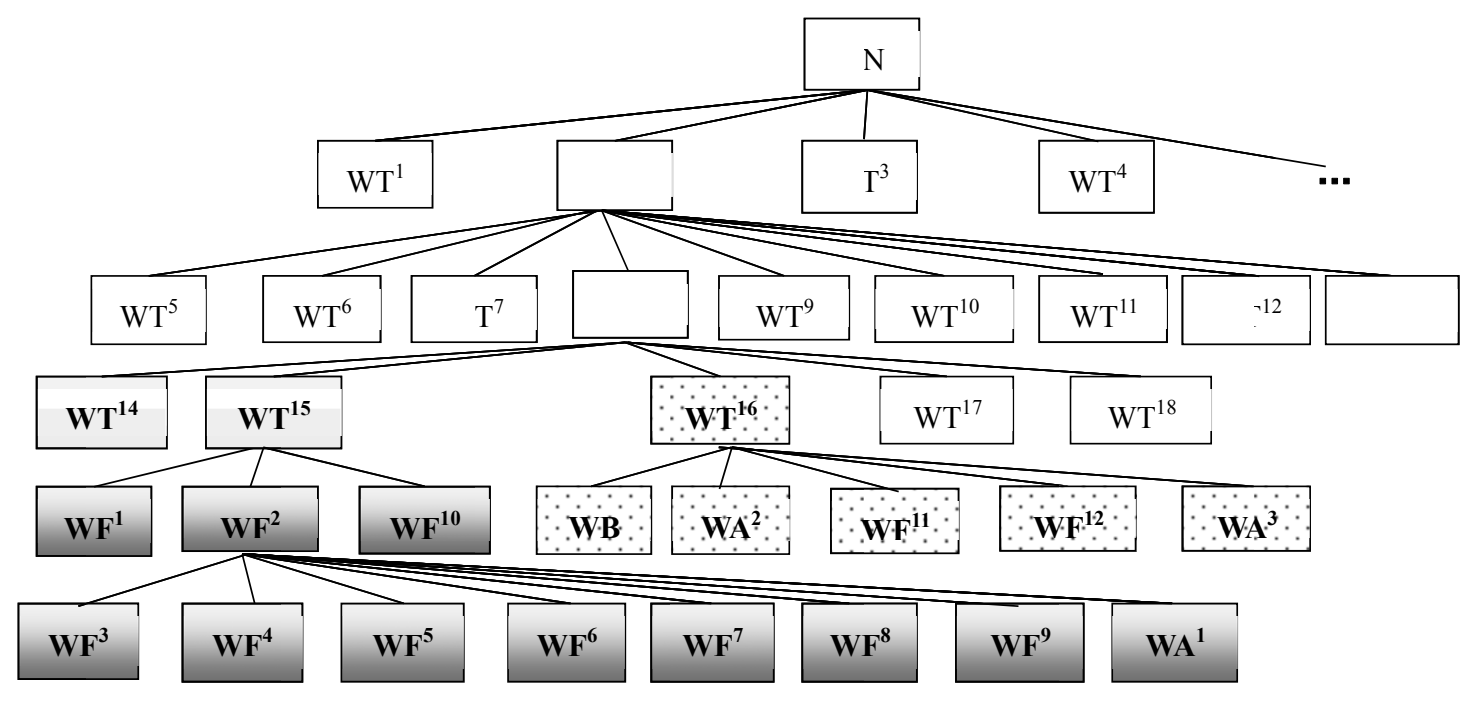

Figure 2. Information structure of extract 2

Whether the plaintiff is the eligible subject of this case is a fundamental question. If the plaintiff is deemed as the ineligible subject of this extract, then the court will not accept their lawsuit and their litigation appeals will go in vain. Thus, the plaintiff must try his best to present evidence to persuade the chief judge that he is the eligible subject, while the defendant must strive to challenge or be against the plaintiff's proof presentation.

The plaintiff's intention is to testify that he is the eligible subject of this case. In order to achieve this intention, the plaintiff has presented the evidence which is in favor of realizing the intention. In contrast, the defendant's 
intention is to challenge the plaintiff's proof presentation and to prove that the plaintiff is not the eligible subject of this case.

In order to attain their respective intentions, both the plaintiff and the defendant adopt different types and numbers of information units. And the usage and structure of discourse information of Extract 2 can be seen in Figure 2 .

Figure 2 shows the information structure of Extract 2. In the figure, WT2 refers to the court investigation and the information units from WT5 to WT13 are the development of WT2. Among the information units, WT8 is concerned with the issue of whether the plaintiff is the eligible subject of the case. Among the development of WT8 information unit, WT15 is the plaintiff's evidence presentation to testify his eligible subject of the case, while WT16 is the defendant's evidence which is to challenge the plaintiff's presentation.

Moreover, to make it easier to distinguish the plaintiff's evidence presentation and the defendant's evidence challenge, the part of plaintiff's evidence presentation is shown in gray, while the defendant's evidence challenge part is in scattered dots in Figure 2.

This round of interest contention occurs at the stage of defining conflict and interests. In this round, because the plaintiff wants to testify that he is the eligible subject of the case, he has collected the evidence of WF1, WF2 and WF10 units to realize his intention which is in favor of his interest contention as much as possible and the information units from WF3 to WF9 together with WA1 have presented the evidence in detail. Thus, it can be found that the plaintiff has developed L3, L4 and L5 three levels of information to present his evidence, and that specific evidence in detail is presented by means of seven information units including information units from WF3 to WF9 together with WA1 as the sub-development of WF2 unit. Comparatively speaking, the defendant only uses two information levels of L3 and L4 and five information units, namely, WB, WA2, WF11, WF12 and WA3 to challenge the plaintiff.

In this interest contention, the plaintiff's usage of so many WF information units (from WF1 to WF10) is to increase the objectivity of the facts and to persuade the court that he is the eligible subject of the case. And those WF information units do help the plaintiff effectively to realize his intentions.

\subsection{Discourse Analysis of the Effect of Consensus Change}

Liu et al. (2012) argue that the consensus-building process results from the change in mental models between negotiators. And the consensus change is related to the mental or psychological changes. In the process of business dispute settlement, the consensus change of both disputing parties affects the development of their interest contention. And the consensus may expand or contract in this interest contention in dispute settlement. This consensus change, together with different combination patterns of information units, promotes the interest contention in business dispute settlement. Thus, this section deals with the effect of consensus change on interest contention in business dispute settlement.

\section{Extract 3}

01[审判长]: $<\mathrm{WB}>$ 依照法律规定处理你们问题 的方法, $<\mathrm{WT} 1>$ 可以开庭进行调解, $<\mathrm{WA} 1>$ 你 们考虑一下看如何?

02[原告]: <WA2>我同意调解, 不管怎样说, 只要早把钱给就行了。

03[被告]: <WA3>我也同意调解, 欠钱是实, 还钱也应该, 不过我没欠原告说的那么多, 我 们只欠原告 85177.00 元。 $<W F 1>$ 现在还有个实 际问题, 许多工程没有结, 没有钱要拖一段。

04[审判长]: <WA4>原告看是否少推一段时 间, $<\mathrm{WF} 2>$ 欠款数也不和你说的那样。

05[原告]: <WA5>现在不能马上给可以拖一段 也行, 按 85177.00 元给也行, $<\mathrm{WT} 2>$ 被告说具 体一点我听听。

06[被告]: <WA6>我们愿意将欠原告的工程款, 抓紧时间付清, 要在一九九八年五月底前将欠 原告的工程款人民币 85177 元全部付清, 并承

$01[\mathrm{~J}]:<\mathrm{WB}>$ According to the provisions of law concerning your disputes, $<$ WT1 $>$ mediation can be conducted in this court session. $<$ WA1 $>$ What do you think?

02[P]: <WA2>I agree. Anyway, it's better to have the money back early.

03[D]: $<$ WA3 $>$ I also agree on mediation. It's true that I owe the money and I should repay it. However, I do not owe so much as Plaintiff said. We only owe Plaintiff 85,177 yuan. $<$ WF1 $>$ And the practical problem is lack of money before the completion of many of the projects.

04[J]: <WA4>Plaintiff, is it OK to put off a little? $<\mathrm{WF} 2>$ Besides, the sum is not as you said.

05[P]: <WA5>If you cannot give me now, you may put it off a little. It is OK if you pay 85177 


\section{担全部诉讼费。}

07[原告]: <WA7 >我同意被告的意见，如果一 九九八年五月底前将欠我的工程款 85177.00 元 全部付清给我, 诉讼费问题我就承担了, 如果 被告说话不算数, 我还将找被告要违约金, 要 利息, 被告说话算数按时付就算了, 同时应考 虑我还收近二万元。

08[被告]: <WA8>先按 85177.00 元付, <WA9> 至于说应按 100281.87 元付的事, 我必须回去 和田 XX 共同研究, 因为他是具体实施人, 他 最了解情况, 今天就这样调解结案, 别的事另 说。

09[原告]: <WA10 $>$ 可以回去查查再说吧, 你先 付这八万多。

10[审判长]: $<\mathrm{WT} 3>$ 请阅读笔录无误签字。 yuan. $<$ WT2 $>$ Defendant, would you give me some details?

06[D]: $<$ WA6 $>$ We are willing to clear the overdue payment we owe Plaintiff...

07[P]: <WA7> I agree with Defendant on this. If you pay up the total sum 85,177.00 yuan before the end of May, 1985, I'll bear the cost of the case. If Defendant fails to keep to his promise, I will demand in addition a penal sum...

08[D]: $<$ WA $8>$ Now, I'll pay the 85,177 yuan first $\ldots<$ WA9 $>$ As for the 100281.87 yuan...

$09[\mathrm{P}]:<\mathrm{WA} 10>\mathrm{It}$ 's $\mathrm{OK}$ to have a check-up first. You pay this sum of around 80 thousand first.

$10[\mathrm{~J}]:<$ WT3 $>$ Please read the record and sign it if it's free of mistakes.

(data source: $\mathrm{Du}, 2013$ )

In this extract, the interaction occurs at the stage of testing solutions. At the stage of testing solutions, the possible solutions for the business dispute settlement are proposed and examined through the conflicting parties' interest bargaining and contention. If the solution is helpful for the dispute settlement, then the solutions will be accepted at the next stage of evaluating solutions. If the solution cannot help to solve the business dispute, then both conflicting parties will resort to other solutions to test whether the solutions are useful to settle the dispute.

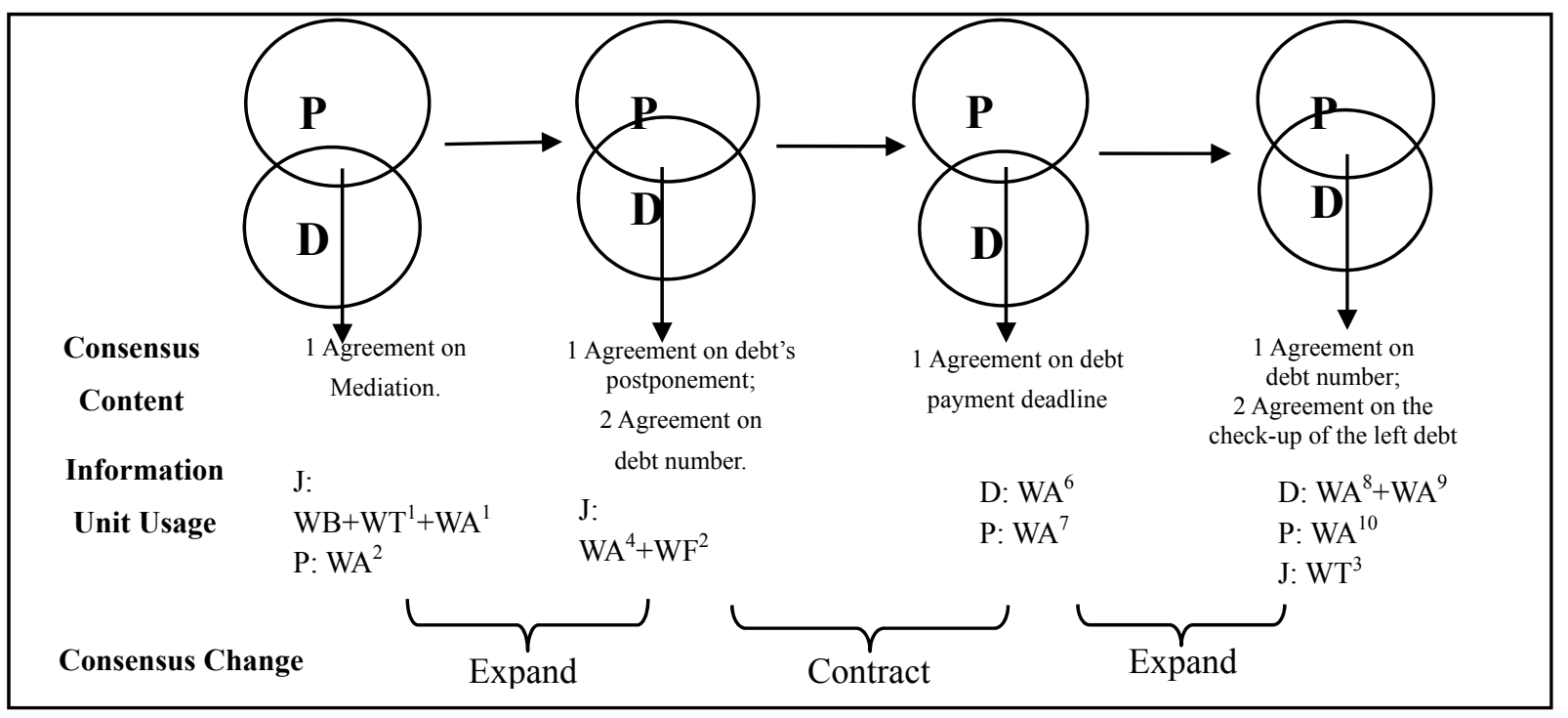

Figure 3. Features of Consensus Change in Extract 3

As can be found in this extract, the plaintiff's and the defendant's consensus on the disputing focus of debt number is changing with the development of the court mediation.

The plaintiff's and the defendant's consensus changes are illustrated in Figure 3. The conflicting parties of both the plaintiff and the defendant usually make the concession to give up certain interests or bear more losses proactively in order to achieve more interest ( $\mathrm{Du}, 2009)$.

In this extract, the plaintiff has made certain concession to conserve a certain amount of the debt, which is also in favor of the successful development of the court mediation. At the beginning, both parties agree to resolve the dispute through court mediation. And the consensus between the plaintiff and the defendant is quite little in that 
although the defendant has admitted that he has owed the money and he should repay it, he does not owe so much as the plaintiff has said. After several turns of bargaining, the amount of debt $(85,177$ yuan) is agreed upon by both parties and the consensus between them has expanded from the original agreement on mediation like "我 同意调解” (I agree on mediation) to the agreement on both the postponement of the debt and debt number, e.g. “现在不能马上给可以拖一段也行” (If you cannot give me now, you may put it off a little) and “按 85177.00 元 给也行” (It is OK if you pay 85,177 yuan).

As can be seen in Figure 3, the plaintiff's and the defendant's consensus changes are based on both disputing parties' interest bottom line. And their mutual interest bottom line is “按 85177.00 元给也行” (the agreement on the 85,177 yuan payment of the debt). Based on this agreement of the least debt payment, the plaintiff is willing to make the concession to give up other interest, such as the litigation cost, the postponement of the debt payment before the end of May in 1998, and the negotiation on the other 20,000 yuan after this court mediation later.

With respect to the information features of the consensus change, both the plaintiff's and the defendant's views are mainly expressed by means of WA information units. WA2, WA5, WA7 and WA10 show the plaintiff's attitudes on the possible solutions to settle the dispute, whereas WA3, WA6, WA8 and WA9 express the defendant's consensus changes on the possible solutions for the dispute settlement. And the WA plus WF information unit pattern is also used. In this WA plus WF information unit pattern, WF information unit is utilized to provide objective support for the previous attitude conveyance.

Besides, it can be found that the consensus of both parties may expand or contract with the development of the mediation on debt payment in this case. And the dispute settlement process can be continued and prompted if the consensus of both conflicting parties equals to or is more than their interest bottom line of the agreement on the 85,177 yuan payment of the debt. Thus, the plaintiff's and the defendant's consensus change on debt payment promotes the settlement of this debt payment dispute.

\subsection{Discourse Analysis of the Effect of Information Sharing Category}

Discourse information can be classified into six information sharing categories, namely, A, B, C, E, O and D in monologue, a, b, c, e, o and d in question, R, S, T, Y, Z and U in dialogue (Du, 2015). Ge (2014) proposes that these categories are different both in mutual manifestation, acceptability and different degrees of information sharing. Different information sharing categories affect interest contention in business dispute settlement.

Among all the categories, for example, category "e" in question, which refers to information that is unknown to both $\mathrm{A}$ and $\mathrm{B}$, has the lowest degree of information sharing. In this way, this category "e" may hinder the information flow and affect interest contention between the disputing parties.

\section{Extract 4}

01[审判长]: $<\mathrm{WT}, \mathrm{b}>$ 你说明一下 你现在补充的是哪些证据?

02[原代一]: $<\mathrm{WF} 1, \mathrm{a}>$ 补充的证据 第一个就是被告 app 端口在微博 平台的读取记录。 $<\mathrm{WF} 2, \mathrm{a}>$ 就是 刚才我们说的究竟被告 app 读取 的是什么样的内容? 有没有读取 教育、职业信息？<WF3，a $>$ 就是 我们后台的记录我们通过一些相 关的电子证据予以提交证明被告 通过被告 app 是没有抓取任何的 职业、教育信息的。 $<W Y, a>$ 因为 他没有这个权限, 所以他抓取不 到, $<\mathrm{WF} 4, \mathrm{a}>$ 这是第一份证据。 $<$ WF5, a $>$ 第二份证据就是刚才马 老师说的爬虫抓的它一定有记录, 确实我们有记录。 $<\mathrm{WF} 6, \mathrm{a}>$ 我们 第二份证据, 证据 20 就是微博账 号、被告 app、 $x \times$ 网在微博平台的 抓取记录。<WF7, a 我们从 2012 年一直到 2014 年这段期间去观测
$01[\mathrm{~J}]:<\mathrm{WT}, \mathrm{b}>\mathrm{Can}$ you explain the supplementary evidence which you have added?

02[PA1]: $<\mathrm{WF} 1$, a $>$ The first piece of supplementary evidence is the record read by the defendant's app port in the microblogging platform. $<\mathrm{WF} 2$, a $>$ That is, we just say what kind of content is read by the defendant's app? Is there any reading of information concerning education and profession? $<\mathrm{WF} 3, \mathrm{a}>\mathrm{It}$ is the records of our background. We've presented relevant electronic evidence to prove that the defendant has not crawled any information concerning profession and education by logining the defendant's app. $<\mathrm{WY}$, a $>$ Because the defendant did not have this authority, so the defendant cannot capture the information. $<\mathrm{WF} 4, \mathrm{a}>\mathrm{This}$ is the first piece of evidence. $<$ WF5, a $>$ The second piece of evidence is just what teacher Ma said that it must have records if the crawler (a computer program that visits websites and collects information when you do an Internet search) is used to crawl the information, indeed we have the records. $<$ WF6, a $>$ Our second piece of evidence, evidence 20 is the records which crawl the microblogging account, the defendant's app, $\times \times$ network on the microblogging platform. $<$ WF7, a $>$ From 2012 to 2014, we have 
这两个账号在微博上的读取相关 情况, 他看其他人的相关情况, 发 现他抓取了大量的其他人的其他 账户的教育和职业信息。 $<$ WI, a $>$ 这两个相佐证, 就是被告 app 你没 有抓取, 而你被告 app 的微博账号 从被告 app 和 $x \times$ 网这两个账号抓 取了很多信息, 当然他也只能通过 其他的账号去抓取了信息（被打 断) observed what the two accounts have crawled other users in the microblogging, and we find that the two accounts have crawled other users' abundant information concerning education and profession. $<$ WI, a $>$ The two pieces of evidence can prove that the defendant's app has not crawled the information, but the defendant have crawled a large number of information from the accounts of the defendant's app and $x \times$ website by using the microblogging accounts to login, of course, the defendant can only grab the information by means of other accounts (interrupted).

In Extract 4, the questioning occurs between the chief judge and the plaintiff's agent. In this extract, WF1, WF2, WF3, WF4, WF5, WF6 and WF7 provide several pieces of supplementary evidence which have been applied to be presented by the plaintiff. And the pieces of supplementary evidence are new to both the chief judge and the defendant. And the category "a" embraces relatively low degree of information sharing, which is in favor of the plaintiff's contention for interest.

Moreover, a new type of evidence, electronic evidence, has been added to Article 63 of China's Civil Procedure Law according to the amendments to this law in 2002. And this new type of electronic evidence has been presented by the plaintiff lawyer as the supplementary evidence. The new supplementary evidence of WF1 and WF5 provided by the plaintiff focuses on how the defendant has stolen their users' professional and educational information in particular and the specific records of using crawler, which is crucial to testify the defendant's unfair competition behavior on how to steal the plaintiff's users' information concerning education and profession in large quantity.

Among the six information sharing categories, category A/B concerns personal specific knowledge (Xu, 2013) and thus has a low degree of information sharing (Du, 2015). In this way, the category "a" can help the plaintiff gain the advantage in testifying how the defendant steals the plaintiff's users' relative information, which is in favor of the plaintiff's interest contention in the process of this business dispute settlement.

\section{Conclusion}

The present study has analyzed the psychological factors that influence interest contention in business dispute settlement. New findings have been found in the present study. From the data analysis, it can be seen that participants can utilize the psychological factors such as the intentions, consensus changes, and information sharing categories to affect interest contention in business dispute settlement. Specifically, intentions, the starting point of a discourse, is closely related to information potential energy. And the information potential energy in the participants' intentions plays a crucial role in the manipulation of interest contention in business settlement. Moreover, in order to attain respective intentions, disputing parties adopt different types and numbers of information units in their arguments for interest contention. In respect to the consensus change, it is based on disputing parties' respective interest bottom line, and the consensus changes of both disputing parties may expand or contract with the changes of interest contention in business dispute settlement. Furthermore, both disputing parties' views are mainly expressed by means of WA information units. In addition, disputing parties' consensus changes promote the settlement of business dispute. As for the information sharing category, different information sharing categories affect interest contention in business dispute settlement. For instance, category "e" in question, which refers to information that is unknown to both $\mathrm{A}$ and $\mathrm{B}$, has the lowest degree of information sharing. And this category "e" may hinder the information flow and affects interest contention between the disputing parties. What's more, it can be found that the category "a" can help the plaintiff gain the advantage in testifying how the defendant steals the plaintiff's users' relative information, which is in favor of the plaintiff's interest contention in the process of this business dispute settlement.

\section{Author biography}

Tingting Guo received her PhD in Business English Studies from GuangDong University of Foreign Studies. Her research interests include discourse analysis, business communication studies, forensic linguistics and comparative study of English and Chinese. She currently works in the Postdoctoral Research Station of Chinese Language and Literature of School of Liberal Arts of Zhengzhou University.

\section{Acknowledgments}

The research is sponsored by Ph. D Research Programme of Zhongyuan University of Technology [No. 34110495], and the 13th Five-year Key Project Cultivation Programme of School of Foreign Languages of 
Zhongyuan University of Technology. The present research is a partial fufillment of a joint training postdoctoral program between Zhongyuan University of Technology and Zhengzhou University.

The author's sincere appreciation goes to the anonymous peer-reviewers and the editor for their comments on the revision of this article. And the heartfelt gratitude also goes to the assistant editor for her timely mail confirmation and supply of help. I am solely responsible for any remaining errors and shortcomings.

\section{References}

Brown, G., Gillian, B., \& Yule, G. (1983). Discourse analysis. Cambridge University Press.

Chen, J. (2011). The reconstruction of prosecution — defence - judge relationship in China: A frame analysis of judges' discourse information processing. International Journal of Speech, Language \& the Law, 18(2). https://doi.org/10.1558/ijsll.v18i2.309

Chen, J. (2017). A corpus-based discourse information analysis of Chinese EFL learners' autonomy in legal case brief writing. English Language Teaching, 10(4), 150-164. https://doi.org/10.5539/elt.v10n4p150

Conley, J. M., \& O’Barr, W. M. (1998). Just words: Law, language, and power. Chicago: The University of Chicago Press.

Cotterill, J. (2003). Language and power in court: A linguistic analysis of the OJ Simpson trial. Springer. https://doi.org/10.1057/9780230006010

Du, J. (2007). A study of the tree information structure of legal discourse. Modern Foreign Languages (Quarterly), 30(1), 40-50.

Du, J. (2009). A Study of the discourse information features in advanced writing by English majors. Foreign Language Education, 30(2), 42-46.

Du, J. (Ed.), (2013). Discourse analysis. Wuhan: Wuhan University Press.

Du, J. (2015). On legal discourse information. Beijing: People's Publishing House.

Fairclough, N. (1995). Critical discourse analysis: The critical study of language. New York: Longman Publishing.

Fan, Y. (2007). Theory and practice of dispute resolution. Beijing: Tsinghua University Press.

Ge, Y. (2014). Resolution of conflict of interest in Chinese civil court hearings: A perspective of discourse information theory. International Journal of Speech Language and the Law, 21(1), 163-168. https://doi.org/10.1558/ijsll.v21i1.163

Guan, X. (2015). Potential speaker-discriminating power of speaking style: Application of discourse information analysis to forensic speaker recognition. International Journal of Law, Language \& Discourse, 5(1), 38-65.

Guo, T. T. (2017). A study on interest contention in business dispute settlement: A discourse information approach. Unpublished doctoral dissertation, Guangdong University of Foreign Studies, Guangzhou, China.

Guo, T. T., \& Zhao, Z. X. (2019). The discourse analysis of e-business instant communication from the perspective of Politeness Principle. International Journal of English Linguistics, 9(2), 174-188. https://doi.org/10.5539/ijel.v9n2p174

Guo, T. T., Zhao, Z. X., \& Han, X. H. (2019). The discourse analysis of social factors influencing interest contention in business dispute settlement: A perspective of discourse information theory. Asian Social Science, 15(3), 46-57. https://doi.org/10.5539/ass.v15n3p46

Guo, T., \& Zhu, W. (2009). The integrative nature of BE teaching: Knowledge and skills. Asian Social Science, 5(11), 72-75. https://doi.org/10.5539/ass.v5n11p72

Halliday, M. A. K. (1978). Language as social semiotic: The social interpretation of language and meaning. London: Edward Arnold.

Huai, Y. M. (2014). A procedure research on the production and construal of communicative intention from a multimodal discourse information processing perspective. Foreign Language and Literature, 30(3), 90-95.

Huang, Y. P. (2012). A discourse analysis of lawyer information manipulation in Chinese criminal trials. Unpublished doctoral dissertation, Guangdong University of Foreign Studies, Guangzhou, China.

Pan, X., \& Du, J. (2011). Information flow of process control in courtroom question and response. Journal of Foreign Languages, (2), 56-63. 
Spencer-Oatey, H., \& Xing, J. (2004). Rapport management problems in Chinese-British business interactions. Multilingual Communication, 197-222. https://doi.org/10.1075/hsm.3.13spe

Sun, B. (2016). A study on automatic information seeking in Chinese judicial discourse. Unpublished doctoral dissertation, Guangdong University of Foreign Studies, Guangzhou, China.

Sun, B., \& Guo, T. (2017). A corpus-based study on information features of Chinese judicial discourse. Journal of Zhongyuan University of Technology, 28(5), 13-18.

van Dijk, T. A. (2008). Discourse and context: A Socio-cognitive approach. Cambridge: Cambridge University Press. https://doi.org/10.1017/CBO9780511481499

Vestergaard, B., Helvard, E., \& Sørensen, A. R. (2011). Conflict resolution: Working with conflicts. Denmark: Danish Centre for Conflict Resolution.

Wodak, R. (1985). The interaction between judge and defendant. In T. A. van Dijk (Ed.), Handbook of Discourse Analysis (vol. 4: Discourse Analysis in Society, pp. 181-191). London: Academic Press. Harris, 1989

Xu, Y. P. (2013). Realization of persuasion in Chinese court conciliation: The discourse information approach. Beijing: Science Press.

Yang, W. H. (2009) A discourse analysis of interpersonal business negotiations. Beijing: Science Press.

Yuan, C. (2018). A battlefield or a lecture hall? A contrastive multimodal discourse analysis of courtroom trials. Social Semiotics, 1-25. https://doi.org/10.1080/10350330.2018.1504653

Yue, S. W. (2016). Effective information exchange during conflict management in business meetings. Unpublished doctoral dissertation, Guangdong University of Foreign Studies, Guangzhou, China.

Zhang, S. (2016). Authorship attribution and feature testing for short Chinese emails. International Journal of Speech, Language \& the Law, 23(1). https://doi.org/10.1558/ijsll.v23i1.20300

Zhao J. F. (2011). On the information structure and its linguistic realizations in legal discourse: $A$ Chinese-English contrastive discourse analysis. Beijing: Science Press.

Zhong, C. S. (2009). A discursive-psychological study of judges' judicial behavior. Unpublished doctoral dissertation, Guangdong University of Foreign Studies, Guangzhou, China.

\section{Copyrights}

Copyright for this article is retained by the author, with first publication rights granted to the journal.

This is an open-access article distributed under the terms and conditions of the Creative Commons Attribution license (http://creativecommons.org/licenses/by/4.0/). 